\title{
Research on the Formation of Marx and Engels' Communism
}

\author{
Pengcheng Li \\ Nanjing University of Aeronautics and Astronautics \\ Nanjing, China \\ Jiangsu Normal University \\ Xuzhou, China
}

\author{
Yanling Mei* \\ Jiangsu Normal University \\ Xuzhou, China \\ *Corresponding Author
}

\begin{abstract}
Interpretation of Marx's related works reveals the formation of his communist view. The "1844 Economics and Philosophy Manuscript" first expresses the preliminary principles of communism in a systematic theoretical form, and performs criticism for other unscientific communist views, which uses alienation as an entry point to require the elimination of the fundamental opposition between laborers and labor, thus liberating people from alienation and restoring the essence of human "free and conscious activities"; in "German Ideology", Marx and Engels intends to criticize Feuerbach, Powell and Stirner at the same time, which leads to the fall of communism from heaven to earth, and points out the way of communism practice; meanwhile, the description of the ideal of the future communist society opens up an ideal dimension of all-round development of human beings, and outlines the path to communism that eliminates labor, division of labor, and private ownership.
\end{abstract}

Keywords-Marx and Engels; communist view; critical way; sublation

\section{INTRODUCTION}

Scientific communism is based on Marxist philosophy and political economy. It profoundly reveals the inevitable demise of capitalism and the inevitable victory of communism, which helps it become the true science that guides all mankind toward freedom and liberation and become the greatest theoretical results and the most valuable spiritual wealth of the mankind. It is an important part of the entire Marxist theory. However, "communism" is not static in the thoughts of Marx and Engels, but has a process from occurrence to development to maturity, and it is still enriched continuously.

\section{RESEARCH PROCESS}

\section{A. The Communist Viewpoint in the 1844 Economic and Philosophical Manuscripts}

Marx began to pay attention to the study of communism, which could be traced back to the "Communist and Augsburg "General Report" written in October 1842. Here, he saw the fact that communism attracted attention in France and the United Kingdom and its universal significance in Europe, but he did not agree with the utopian socialism and communist doctrine at the time. He believed that "the real danger is not the actual experiment of communist ideology, but its theoretical elaboration." This is the first expression of Marx's attitude towards communism.

In "1844 Economic and Philosophical Manuscripts", Marx first expressed the preliminary principles of communism in a systematic theoretical form. In the chapter "Private Property and Communism", "Communism" was divided into three types and reviewed separately. For the first "rough communism", Marx made a critical critique that this "is just a manifestation of the despicable nature of private property as an active community." It was believed that it only emphasized the materiality of human existence, and essentially transferred property ownership, not to destroy private property. The second kind of communism, Marx divided it into two forms: "(1) it is also political in nature, democratic or authoritarian; (2) it abolishes the state, but at the same time has not completed this task and still under the influence of private property, namely human alienation." He believed that these two forms of communism "have not understood the positive nature of private property, nor do they understand the nature of the people needed, so it is also bound and infected by private property. "The third kind of communism is "private property, that is, the positive sublation of human self-alienation, and thus, it is the real possession of human nature through human beings and for human beings." Because Marx was deeply influenced by Feuerbach's thought of people-first at that time, so he agreed very much on this point of view. "This kind of communism, as a completed naturalism, is tantamount to humanitarianism; at the same time, it is equivalent to naturalism as a completed humanitarian. It is not only the real resolution of contradiction between man and nature, but between man and man, but also the real solution to the struggle between existence and essence, objectification and selfconfirmation, freedom and necessity, and between individuals and classes. It can be seen that communism at this time took the point of alienation as an entry point, requiring the elimination of the fundamental opposition between laborers and labor and further liberated people from alienation and restored the essence of human "free and conscious activities". Since Marx did not form a historical materialism at the time, this humanistic tendency in the "Manuscript" embodied a metaphysical dimension. In short, in the "Manuscript", although Marx criticized other unscientific communist views and embodied rich dialectic thoughts, it still did not fundamentally break away from the shackles of Feuerbach's 
humanistic thinking. Therefore, the communist view here can only be seen as a prelude to his scientific communist view.

In "German Ideology", Marx began to use the basic viewpoint of historical materialism to propose and demonstrate his own communist view. At this time, the communist ideology is more mature and reasonable than the communist ideology he expounded before. New dimensions have been opened with new methods and new perspectives.

\section{B. The View of Communism in the "German Ideology"}

While writing "German Ideology," Marx and Engels intended to criticize Feuerbach, Powell, and Stirner. From 1835 to 1845 , the entire "Young Hegelians" became the masters of the world-wide revolution that swept through all the old forces, but their attempts to get out of the Hegelian maze ended in failure. The starting point for this attempt to get out of the maze was roughly from Strauss's The Biography of Jesus to Stirner's The One and Its Owners. It mainly criticized for religion, so that they were still caught in the thoughts of old Hegel. Among them, Feuerbach has taken a solid step in overcoming the philosophy of the old Hegelian idealism. He clearly revealed that the religious world was the fantasy of the secular world, but he retreated when it came to the question that how people's secular life leads to religious fantasy in their minds. Therefore, his behavior of interpreting the secular world with the words "abstract" and "human nature" was pale and powerless. Stirner published the article "The Only One and Its Ownership" and argued that no moral, political, legal, or social concepts and norms were recognized except for the only individual. At the same time, a "true socialist theory" represented by Hess has also become the object of Marx and Engels to be liquidated in the "German Ideology". "German Ideology" has formed such a "economics-philosophy" dual logic in the philosophical and economic criticism of Liszt's book "The National System of Political Economy", which made communism fall from heaven to the human world and pointed out the practical ways of communism. At the same time, the ideal description of the future communist society has opened up an ideal dimension of human development. These three dimensions are based on the historical materialism, unified in the "German Ideology", and jointly construct the scientific communist view in the "German Ideology".

In the article "Feuerbach", Marx first clearly explained his understanding of the historical development process. He divided history into three phases: the first phase is the community. This stage includes several forms of ownership that have appeared in history: tribal ownership (original community), classical ancient community ownership and state ownership (slavery), feudal or hierarchical ownership (feudalism). The second stage is civil society. As a negation of the original community, it is the limitation breaking of the individual through the community and uniting to form the society, which corresponds to the modern society in front of us. The third stage is the "union" of free people. It is a denial of civil society. The whole world history is developed in the order of "community $\rightarrow$ civil society $\rightarrow$ union of free people." Obviously, the union of free people is Marx's concrete vision of the future society. However, the union is not suddenly produced out of thin air in the future society, but develops in civil society. Due to the exclusive nature of private ownership and the division of social labor, individuals can only satisfy their own desires and realize the value of self by complementing and interdependent. This kind of "need system"(Hegel) formed on the basis of division of labor and exchange is actually a union. However, the union in civil society can only be a union between the private owners. In this union, objects such as commodities, money, and capital are the subject of unity, and individuals are merely the personalization of objects. Moreover, this kind of union and the harmony nature the union should have had are contradicted, and it also contains hostile relations such as class struggle. In the future society, individuals will no longer be representatives of goods, money, and capital, but a free personality liberated from the relationship between alienation and materialization. The class opposition and the false community representing the interests of the ruling class, namely the state also will die. In this situation, the alliance should be a unity of free individuals, and humanity will thus end the "prehistoric period of human society (primitive community and civil society) and enter the period of true human history - communism.

In the scientific communist theory of Marx and Engels, the communist society is the next social form inevitably coming according to the law of social development. Moreover, unlike the imaginary communists who are keen on depicting the ideal society of communism, Marx and Engels put their main focus on the study of historical laws and realistic development trends on the issue of communist ideals. The depiction of an ideal society is limited to the formulation of principles, and all the details are left to history to supplement. As Engels said, the more detailed the description of future communism, the more easily "people will fall into pure fantasy." They knew deeply that the future ideals have so many variables that cannot be determined by logic and reasoning. Only the practice of the witness has the final say. Therefore, Marx has never been arbitrary about the details of communism and has always left room for it. The "German Ideology" only made a preliminary outline of communism: eliminating labor, division of labor, and private ownership.

1) The elimination of labor: Labor is the basic origin of human beings and the confirmation of the essential strength of human beings. However, Marx and Engels have proposed that "communism is aimed at the nature of activities so far to eliminate labor." "In order to realize one's own personality, ... eliminate labor. "This is not a paradox, but Marx and Engels are deeply aware of the enslavement of the labor of earning a living. To realize the all-round development of human beings, it's necessary to be freed from earning a living. Therefore, it is not the general work of mankind, but the labor of earning a living that to be eliminated. In the communist society, labor becomes a free and conscious activity, the first need of life, and the means and enjoyment of people's all-round development.

2) The elimination of division of labor: "German Ideology" believes that the existence of communism as "world history" will eliminate the division of labor. The division of labor is actually a different combination of laborers and 
production tools in the production process, and it is the technical performance of labor. Therefore, the elimination of labor implies the elimination of division of labor. Because the human form of technology will last forever, it is not to eliminate the spontaneous division of labor based on public property ownership but on the basis of private ownership, and to replace the spontaneous division of labor with voluntary division of labor. At this time, human exists in a selfdiscipline way. "In a communist society, no one has a special scope of activities, but they can develop in any department. The society regulates the entire production, thus making it possible for me to follow my own interests to do anything. It will be ok to hunt in the morning, fish in the afternoon, engage in animal husbandry in the evening, and be cautious after dinner, so that I don't always be a person of a hunter, fisherman, shepherd or critic."

3) The elimination of private ownership: Private ownership is the result of past labor. Therefore, the elimination of labor also implies the elimination of private ownership: "communism and all past movements differ in that communism overthrow the foundations of all old production relations and communication relations, and for the first time, it consciously regards the premise of all spontaneous formation as the creation of predecessors. The spontaneity of these preconditions should be eliminated, so that they are governed by the united individuals. Therefore, the establishment of communism is essentially economic in nature, which means to create various material conditions for this union and turn existing conditions into joint conditions." Only in this way can laborers occupy the sum of all the productive forces they create and create conditions for individual autonomy.

\section{The Content Interpretation of Marx's Communist View}

For a long time, people have been accustomed to understanding Marx's communism from the perspectives of communism as a theoretical doctrine, a social system, a practical movement, and a social ideal.

The understanding of the communist view must pay attention to the two basic dimensions of this important ideological connotation: first, the reality dimension refers to a perfect social system and a platform that can be reached through revolution and construction. Marx elaborated on the necessary conditions for realizing communism in the "Communist Manifesto", "Capital" and "Critique of the Gotha Program". These conditions are the opposites of the capitalist society. Although they are not empirical, they are logically evokable. In this sense, communism is the ideal goal that must be achieved. The second is the metaphysical dimension or the philosophical dimension, which refers to the ultimate solution to the possession of human nature and the various contradictions in objectification activities. The 1844 Economic and Philosophical Manuscripts, as the origin of Marxist philosophy, made a wonderful exposition of this dimension of communism: "communism is an active sublation of private property, that is, human self-alienation, and thus, it is the true possession of the essence of man through people and for people. Therefore, it is the return of man to himself, to the society, that is to the humanity ... it is the real solution to the contradiction between the human and the natural world, between man and man..." Obviously, this dimension of communism is completely a kind of ambiguity in the philosophical sense of the future development of human beings. Although its proposed goals are imaginable, it is difficult to operate, and people do not know when and under what conditions can they achieve the possession of the essence of man, especially that how to truly resolve the contradiction between man and nature and between man and man. In the current imagination of people, this can only be a metaphysical dimension. The interpretation of re-occupation of the essence of man and the real solution to the contradiction between man and nature and between man and man clearly in the 1844 Economic and Philosophical Manuscripts bears the metaphysical philosophical imprint. Although this ideal pursuit is closely related to people and seeks for perfection of human beings with enlightenment, it always gives people a puzzle that is difficult to grasp, just as people think of heaven but don't know how to enter heaven.

The "German Ideology" changed the abstract thinking of communism in"1844 Economics and Philosophy Manuscript" and thoroughly perceptualized and realisticized communism with the formal establishment of the practical materialist worldview, and opened up practice ways to realize communism from different perspectives with the ultimate goal of realizing the comprehensive development of people.

1) Marx's description of communism in the "German Ideology" is more realistic and reasonable: Communism isn't limited in the elimination of alienation and the return of human nature to human beings. It is based on the elimination of the actual ills of capitalist society and is a new realm that can be achieved through revolutionary practice. During his life, Marx predicted the occurrence of the European revolution many times, and imagined in the "German Ideology" the good life scene of the people in the communist society after the elimination of the division of labor: "no one has any special scope of activities, but can be in any development within the department. The society regulates the entire production, thus making it possible for me to follow my own interests to do anything. It will be ok to hunt in the morning, fish in the afternoon, engage in animal husbandry in the evening, and be cautious after dinner, so that I don't always be a person of a hunter, fisherman, shepherd or critic."The famous depiction of the communist vision is very fascinating, and contemporary people who suffer from the forced division of labor are all sloppy and embarrassed. With the shortening of working days and the improvement of people's multi-faceted qualities, the ideal realm of such comprehensive development of people depicted by Marx becomes more and more acceptable and receivable.

2) Communism is a business of "world history" to be completed in world history: For the first time in his "German Ideology", Marx explicitly put forward the thought of world history and linked it to the communist revolution, which is regarded as a necessary condition for realizing communism. 
Marx believes that the big industry of capitalism has not only opened up the domestic market, but also opened up the international market, thus increasing people's exchanges and the boundaries and gaps between the nation and the region have been gradually being broken, and the various ethnic groups have been increasingly interdependent and will form the whole process of world unity. This process is the formation of world history. World history has a major impact on the survival and development of human beings: in the course of world history, the isolated existence of individuals under the original natural economic conditions has become a historic existence of interconnected world. As Marx said, productivity development has made "the existence of people's world history rather than territoriality is already the existence of experience", and thus "regional individuals have been replaced by world-historic and experienced individuals." This world-historic personal existence is first reflected in the proletariat: the proletariat is a world-historic class, and connected with the big industry and the world market, so the communist cause of the proletariat is also the historic cause of the world. Marx said: "any expansion of communication will destroy regional communism.... the proletariat can only exist in the world-historic sense, just like communism - its cause only possible as a 'world-historic' existence." In this way, Marx not only pulls communism from heaven to the human world, but also indicates that "communism can be possible in experience only when dominant nations take actions at the same time". The significance of Marx's idea is not in its realistic possibility, but in that it has paid attention to the conditions and ways of realizing communism, which is a big improvement compared with the "Manuscript".

3) Communism is a never-ending process of practice: In "1844 Economic and Philosophical Manuscripts", Marx put forward the lofty mission of communism to eliminate alienation, to make people fully possess their own essence and finally to resolve the contradiction between man and nature and between man and man, but for the existence of mankind, this mission is very difficult to complete. Similarly, the contradiction between man and man and people and nature is difficult to eliminate at once. If this contradiction does not exist, people will have nothing to do, and there will be no human life and history. Therefore, this high-level goal of communism proposed by Marx can only be achieved with the human peers and in the endless history of all mankind. This situation forms a paradox with the realistic dimension of communism: the reality dimension indicates that communism can be achieved as long as the necessary conditions are met, but the metaphysical dimension here says that communism can only be reached in the "all movements of history" or "in reality, it will be achieved after going through a hard and long way". There is a famous assertion responsive to the paradox in the "German Ideology" that communism is a process of practice generation. He said: "communism is not a situation that should be established for us and not an ideal that reality should be compatible with, but a reality movement that we call communism to eliminate the existing situation." Marx's famous saying on the one hand clarifies the simple understanding that communism is just limited to a platform that can be reached. On the other hand, it points out that communism is a kind of movement and it is generated in the extinction of the existing situation, and a practical process of creating a comprehensive development. Therefore, communism is not an unreachable future, but lies beside our sides and in our actions: every step we take to eradicate the old world and build a new world is to accumulate strength for the realization of communism, all of which is the constituent parts of communism. In this way, Marx not only attributed the world to people and their practices, but also adhered to the fundamental purpose of materialism in dealing with communism, and ultimately attributed communism to the perfection of human beings as well as the necessary practical process of transforming reality. Thus, it reflects the powerful radiation and internal integrity of Marx's practice laws.

\section{CONCLUSION}

Communism as envisioned by Marx is not only a physical world that can be reached, but also a metaphysical realm that cannot be reached at a specific time. It is the realm of practice that unites the physical realm with the metaphysical realm. This is the theory Marx firstly proposed in the "German Ideology". Marx said: "communism is not a situation that should be established for us and not an ideal that reality should be compatible with. It is a kind of reality movement that eliminates the existing situation." Movements and activities are in the synonym of practice. Marx pushes the opposition between the physical realm and the metaphysical realm to practice and regards practice as a union. This is a wonderful solution to the opposition between the two. The reality of practice cannot reach the metaphysical realm of communism at any time. It is impossible to eliminate alienation and take possession of essence, and resolve various contradictions of objectification. However, practice accumulates new qualities at every moment, and meanwhile, it constantly tends to and approaches metaphysical realms. Therefore, practice is both a physical realm and a metaphysical realm and the unifiedhistoric unity of the two in real life.

\section{REFERENCES}

[1] The fourth volume of Selected Works of Marx and Engels. People's Publishing House, 1972 edition, Page 237, 236, and 227.

[2] The fourth volume of Selected Works of Marx and Engels. People's Publishing House, 1972 edition, Page 208, 218.

[3] Marx, 1844 Economic and Philosophical Manuscripts, Translated by Liu Pikun, People's Publishing House, 1979 edition, Page 2 and 3.

[4] The third volume of The Complete Works of Marx and Engels, People's Publishing House, 1960 edition, Page 83-84.

[5] The third volume of The Complete Works of Marx and Engels, People's Publishing House, 1960 edition, Page 30. 